\title{
The Dutch Courtesan and 'The Soul of Lively Action'
}

\begin{abstract}
The Dutch Courtesan has traditionally been the subject of critical interpretations which offer simplified accounts of both its overall design and its scene-by-scene complexities. This article charts some of the recurrent problems that have, in particular, affected scholarly accounts of the Freevill/Malheureux/Franceschina plot, which became apparent as the author worked on the play in production. The aim is to map more clearly some of the key givens of the script, but not to dictate performance outcomes, since the play is sufficiently rich to invite and to accommodate contrasting realizations on stage.
\end{abstract}

The Dutch Courtesan offers the most ambitious assembly of narrative materials of any of John Marston's plays. It deftly combines three plots, each with a distinctive atmosphere, and unites them all in its final scene, as characters from two of the plots face death by hanging. This article grows from my experience of directing the play in $2013 .{ }^{1}$ As a long-term devotee of early modern drama, I already knew the script well and relished the high adrenalin potency and stylistic variety of its writing. Its dialogue seemed to me to cry out for realization in performance. Preparing for rehearsals, I re-explored the scholarly inheritance and have since kept up to date with subsequent publications on the play. The gap between rehearsal room discoveries and the default emphases of published analysis turned out to be substantial. What follows seeks to map selected aspects of the play where that divide seems widest to me.

In rehearsing a production, the devil is always in the detail. In my view, too much of the commentary I read tends to tidy the provocative intricacy of the play's action and characters into static formations and, by so doing, tames the mercurial, lightning transformations - of dramatic mood and of narrative direction and expectation - which constitute one of the key distinctions and the principal performance largesse of this extraordinary play. Doubtless multiple factors

Michael Cordner (michael.cordner@york.ac.uk) is professor of Theatre, in the department of Theatre, Film, Television, and Interactive Media at the University of York, UK. 
account for mismatches between script and the tradition of commentary. But I would argue that one key one is the pressure scholars experience to offer synoptic accounts of tonally complex and performatively volatile plays within the constraints of a few pages in a monograph or in an article of, typically, only 6,000 to 8,000 words in length. Space constraints of this kind ineluctably breed diagrammatic simplification.

Marston's characteristic theatrical pyrotechnics resist this treatment even more emphatically than does the work of his theatrical peers. But commentary on The Dutch Courtesan by no means represents a unique instance of a tendency to subdue the unruly energies of great dramatic writing to generalized headline accounts, which risk scanting the features that give such writing its true theatrical distinctiveness. My article therefore aims both to offer a new perspective on The Dutch Courtesan and, in that process, to raise some questions about how easy it is for concise scholarly treatments to misrepresent the demanding intricacy in performance of the best early modern writing for the stage. In the pages that follow I will sometimes be sharply critical of the views of the play propounded by distinguished scholars. I have nerved myself to do this, despite being only too well aware that some of my own earlier work is vulnerable to comparable accusations. The insidious pressures of limited word count have worked their effects on my writing also. So an element of mea culpa arises in this essay. But my increased work in the rehearsal room over the last two decades has made me rethink my priorities in this respect, and the current article is one of the results of that rethinking.

I could not have written it if I had not directed the play. But I should make clear how that experience will be reflected here. I do not, on this occasion, intend to talk in detail about particular wrestlings in rehearsals with this or that sequence, or to recount, say, a sequence of experiments in how a specific encounter might be realized in performance. I hope to return to that kind of analysis on another occasion. For the present my concern will mainly be with larger sequences of action. Nor does the article aspire to answer conclusively the questions about the play which it raises. By their nature, they admit of multiple, contrasting solutions in performance. The aim is to identify some of the key givens in the script which, from my perspective, have been obscured by the recurrent presuppositions that much of the writing the play has inspired.

\section{Meeting Marston's Interpretative Challenges}

Scholarship has rarely engaged with the sheer plenitude of the experience Marston offers us. Instead, a couple of discrete areas of the play — particularly the 
Freevill/Franceschina/Malheureux plot — have absorbed most of the attention, with parts of it remaining almost entirely neglected, and others being sometimes explicitly downgraded. Take, for instance, this observation by Mary Bly: 'Crispinella similarly rants against her sister Beatrice's comment that she "[speaks] too broad"'. But Crispinella is expressly a secondary character, a sidekick to the fair and chastely spoken Beatrice.' I am unsure what 'expressly a secondary character' means. It posits a novel species of character which comes with label attached: do not regard anything this character says as being of the same potential significance as speeches by characters higher placed in the dramatic pecking-order. How we might distinguish these two kinds of character from one another Bly leaves unexplained. ${ }^{3}$ Her proposition looks particularly suspect when applied to a character whose dialogue contains such scornful puncturings of conventional pieties as Crispinella's does. The role's performer is given a series of scorching one-liners likely to embed themselves in spectators' memories. Notice, also, Bly's choice of the verb 'rants' to describe Crispinella's retort. The latter's responses to Beatrice's criticism of her free speaking include material lifted from one of Montaigne's most provocative essays ${ }^{4}$ - a source not usually regarded as being characterized by ranting. Finally, the notion of Crispinella as merely a 'sidekick' to her sister begs multiple questions. Ask a performer which of the two roles seems to offer the richer opportunities. Hardly any will answer 'Beatrice'.

Bly's move, however, is not unique. Donna B. Hamilton accords Crispinella greater status than Bly, but counsels us not to take seriously her tussles with her suitor Tisefew: 'While the wit-combat gives the appearance that they are quarrelling, the reality is that they are in love. Neither lover takes the conversation seriously, but both are serious about their love. Love precedes the language which follows merely as an external formality'. ${ }^{5}$ How can Hamilton be sure of this 'reality', if it precedes language - ie. the dialogue of the play, the only data available to us? I can imagine a writer attempting to support this view via a close analysis of these characters' major 'wit-combat' in 4.1, though I remain skeptical about the chances of ultimate success. Hamilton, however, simply asserts the truth of her interpretation as if it were self-evident. She thus reduces the two characters' often combative duologue to a matter of a mere 'external formality'. Consequently, an article examining the play's uses of language empties language, in this instance, of all significant meaning - especially problematic when the encounter in question starts with Crispinella's protestations, to the man who seeks to marry her, about the tyrannous nature of the power society awards to men over women. I doubt if I would be received with joy if I told two actors that they should disregard 
everything which is overtly at stake in their exchanges and play them instead as a seventy-one-line reiteration of the fact that they are 'serious about their love' 6

Other characters have received similar treatment. David Crane repeats, for example, a familiar critical line on the eponymous character, Franceschina: 'When she does speak it is with an accent that to a seventeenth-century English audience habitually out of love with foreigners largely blocks out the notational authority of words'. Again the instruction is to disregard the specific force of Marston's lines, in favour of a performance style calculated to deny them meaning. The route to this conclusion is via a reification of early modern English spectators into a chauvinist stereotype. ${ }^{8}$ That stereotype then justifies a claim that we are not intended to treat what Franceschina says seriously.

Such pre-emptive strikes, if heeded, will anaesthetize our capacity to be surprised by what Marston has actually written — if, for instance, Franceschina started landing effective blows against the lover who is now discarding her. What about her indictment of the misogynist maltreatment she believes she has been subjected to? 'O vnfaithful men, tyrantes, betrayers, de very enioying vs, looseth us, and when you onely ha made vs hatefull, you onely hate vs.' ${ }^{\prime}$ At the very least, this riposte exhibits someone capable of drawing blood in a quarrel. In the first quarto's spellings (as above), only two words here arguably testify to Franceschina's origins: 'de' for 'the', and, more debatably, 'ha' for 'have', though 'ha' is also a common elided form for 'have' for English speakers in this period. In a pattern common in the early printings, whenever Franceschina's lines gather special force (as, I would argue, happens here) the notation of her accent as foreign becomes lighter in touch. Instructing a performer that, even so, they should colour such a rebuke in a manner which will neuter its 'notational authority' looks counterintuitive. Why would Marston craft such a piercing accusation if he wanted performers to undermine its ability to hit home by the way they deliver it?

Malheureux has been the victim of parallel tactics. I will let M.L. Wine speak for many other writers:

Malheureux may seem tragic to himself, but whatever is tragic about 'passionate man' is from the comic vision melodramatic at best and absurd at worst; and it is from the comic vision - from the vision of the thinking, not feeling, mind - that the play derives its structure. On no level of plot does Marston permit us to become seriously involved. ${ }^{10}$

Here too, a move with massive consequences depends on a questionable premise. If all comedy were indeed so unrelentingly cerebral in its design, then what Wine 
proposes might be plausible - if we could also demonstrate that Marston had the same constrained generic definition in mind when writing his play and had designed it in conformity with that definition. But Marston never assigned a generic label to it, calling it 'easy' and 'slight' in the Prologue $(1,16)$ and leaving it at that. Plus, comedy is a house with many mansions, and its diversity includes modes which combine moments of empathetic involvement with sequences where derision dominates. ${ }^{11}$ Finally, Marston himself is notorious for his slipperiness in handling audience expectations. So, why seek to confine the possibilities of what he might have achieved in this way? As with our earlier examples, Wine's assertions are unaccompanied by textual investigations which might lend plausibility to his headline claims. In the end, such a critical approach unhelpfully interposes itself between the script's moment-by-moment impulses and the responses of readers and potential performers.

Matching problems can arise with something as apparently straightforward as plot-summary. In one of the great achievements of contemporary research into this period, their multi-volume catalogue of pre-1642 British drama, Martin Wiggins and Catherine Richardson describe the play's concluding movement thus: 'Cocledemoy, disguised as a sergeant, talks Mulligrub into equanimity, then reveals himself, secures his release, and returns his property. Freevill and Beatrice decide to be married at once. ${ }^{12}$ But the dialogue records no such decision by Freevill and Beatrice. In addition, Beatrice has no lines in the last scene, nor does the script indicate any interaction between her and Freevill. Finally, Freevill's last words are spoken 116 lines before the play's end. After that, the stage is dominated by Cocledemoy's stratagems and the tying-up of the Mulligrubs' story. The summary Wiggins and Richardson offer effectively re-orders the play into an implicit hierarchy in which Freevill's fortunes rank highest. It thus obscures one of the scene's most intriguing aspects, self-evident once you observe it in action - ie, the high percentage of characters who might, at key points, in another dramatization of this story, intervene vocally, but to whom Marston gives no dialogue. That includes making the hitherto overwhelmingly articulate Freevill a mute spectator, in the scene's concluding half, of events he is not permitted to influence, or even to annotate ironically in his previously familiar sardonic style. This silence is a major re-sorting of dramatic emphasis.

Noting this fact identifies a previously unremarked similarity between Marston's play and Measure for Measure. That some kind of cross-dialogue is active between the two has often been remarked; but priority of date between them and, with it, the direction of the flow of influence between the two dramatists have proved difficult to establish incontrovertibly. Since Philip McGuire's work on the 
play, it is a critical commonplace that 'Measure for Measure provides the most challenging and complex example of Shakespeare's use of open silence'13 — 'open', because the silences of six of the comedy's characters in its final movement have inspired radically divergent interpretations, with transformative consequences for the play in performance. The Dutch Courtesan offers its own variant on this phenomenon. In effect, the way in which Wiggins and Richardson fill in one of Marston's open silences necessitates a mimed agreement about their futures between Freevill and Beatrice, thus assuring their story the kind of affirmative ending these scholars appear to prefer. But what would the arguments for and against such a staging choice be, and what alternative readings might the script accommodate, or invite?

If Freevill is rendered silent in the play's last phase, Tisefew, one of Freevill's circle of gallants, is not. In its final fifty lines Marston allows him four brief interventions. The first two are jokey responses (of the kind which earlier have been Freevill's forte) to Cocledemoy's 'flattering' knavery (5.3.144-5 and 153). The decision to privilege Tisefew here over Freevill is therefore noteworthy. The other two speeches announce Tisefew's forthcoming marriage to Crispinella to her father (5.3.164-5 and 168-9). But he and his betrothed have been on stage for the last 184 lines, witnessing a series of events with momentous implications for Crispinella's sister, Freevill's potential bride. They also contain a significant moment of revelation for Tisefew.

In the preceding scene, the previously disguised Freevill reveals his true identity to Crispinella and Beatrice but not to Tisefew, who shudders with distaste at their being accompanied, to witness the executions of Malheureux and Mulligrub, by (as he thinks) a pander (5.2.135-6). He knows nothing of Freevill's masquerade, or even that he is still alive. He is also unaware that the other three intend to save Malheureux's life, not watch him choke to death on the gallows. Tisefew's indignation at having a pimp as his companion earns him a tonguelashing from Crispinella for his 'heedless ignorance' (5.2.144); but she is setting him up, because she could easily have ended that 'ignorance' herself with a brief explanation. Instead, she has contrived that he will only catch up with events when he watches Malheureux's reprieve from death by his 'dead' friend's selfunmasking. Marston assigns Tisefew no dialogue at that point; but an actor will perceive the need to register the moment at which the penny drops for him, and to calibrate how that discovery impacts upon Tisefew's relationship with Crispinella, who will in turn be poised to observe this moment of sudden revelation, which she has herself engineered. How will she exploit her triumph? The players have choices to make, as the contest between them is sustained into the comedy's final 
movement. This challenge is recognizably the work of a skilled theatrical craftsman who animates his entire stage picture. Marston's insistence that his plays are difficult to comprehend when separated from 'the soul of lively action' ${ }^{14}$ deserves serious heeding.

One of the play's earliest moments has also received commentary which circumscribes its potential range of implication. Its prologue concludes with an invitation to 'Sit then with fair expectance and survey / Nothing but passionate man in his slight play' (15-16). Philip J. Finkelpearl typifies many in confidently identifying this 'passionate man' - Malheureux, whose world-view is overturned as desire for the courtesan Franceschina unexpectedly consumes him. Finkelpearl structures his account of the play around an antithesis between "Young Freevils unhappie friend", as the dramatis personae describes Malheureux' and Freevill himself, who is 'plainly someone who possesses free will'. ${ }^{15}$ So, on one side we have a character utterly subdued by passions to which he thought himself immune, who abandons self-control and moral scruple as erotic fixation overwhelms him, and on the other side a figure endowed with self-knowledge and in lucid command of his own choices and actions.

But why assume that the label of 'passionate man' applies to only one character? Without an indefinite article prefacing it, the phrase is, in early modern idiom, as likely (perhaps more likely) to have signified to spectators 'mankind', or indeed 'humankind', rather than cueing a hunt for one character who uniquely matches the description. Besides, when the Prologue speaks these words, the audience has not met any of the characters, or even heard of Malheureux. So, at that point, whether the label might apply to one or more of the characters we will now meet is an open question.

The first scene opens with the self-dramatizing woes of Mulligrub the vintner. Oxford English Dictionary Online (OED)'s initial gloss for his name is 'A state or fit of depression; low spirits. Also, a bad temper or mood'. ${ }^{16}$ His behaviour justifies Marston's choice from the start. Self-pitying grief engulfs him, inspired by Cocledemoy's theft of 'a nest of goblets' from his tavern (1.1.7). He even, bathetically, aligns the imputed extremity of his own suffering with King Priam's incommensurably more grievous woes (47). Resolving not to remain 'jaw-fallen', he exits the scene professing himself devoted to another, more proactive, passion - a revengeful desire to destroy Cocledemoy (52-3). His history thereafter maps frenetic oscillations between depressive fits and an ardent urge to revenge. Spectators might reasonably identify him as the play's first exemplar of the genus of 'passionate man'. 
As its action grows ever busier, The Dutch Courtesan seems at times set on providing us with a menagerie of people in extreme emotional states. Franceschina definitely qualifies, with her vow that there 'sall be no got [ie, God] in me but passion, no tought but rage' (4.3.43-4). If we trust the woman he aims to marry, Freevill, Finkelpearl's instance of rationality and self-control, is another potential candidate. When he expresses his rapt feelings for Beatrice, his taut intensity disturbs her: 'Dear my loved heart, be not so passionate. / Nothing extreme lives long' (2.1.48-9). Equally, his later diatribes against Franceschina — with their denunciation of her 'prostituted impudence', which he now judges 'Senseless like those by cataracts of Nile' (5.1.79-80) — evidence a passionate revulsion which demands aggravated expression.

Beatrice, a lucid counsellor of moderation in the lines quoted above, has often been monumentalized into that shape by commentators for the remainder of the action, and polarized against Franceschina, in the same way that Freevill and Malheureux have been polarized against each other. For Jill Levenson, for instance, it is a black-and-white case of 'virtuous Beatrice and wicked Franceschina' ${ }^{17}$ Mary Beth Rose develops the same theme more circumstantially:

[Marston's] view of women is remarkably simple and clear. Not surprisingly, the whore Franceschina is complemented by the saint, Beatrice, the idealized Griselda figure whose chastity, unswerving loyalty, and patient goodness convert the hero from profligacy and command his love. ${ }^{18}$

Douglas Bruster adduces a parallel between Marston's alleged tactics and the emphatic polarities of an earlier dramatic tradition:

Marston, with The Dutch Courtesan, borrows from the psychomachia tradition of the Moralities in keeping his female characters cosmetically distinct, associating with the play's wife - aptly named Beatrice, or 'one who blesses' - chastity, faithfulness, unselfish love, and purity, and with Franceschina, the Dutch Courtesan, libido, betrayal, self-interest, and disease. ${ }^{19}$

Examples could easily be multiplied.

An approach I find helpful when casting a play is to sketch a hypothetical emotional spectrum for each character, ${ }^{20}$ identifying the range across which a player needs to move in order to fulfil the role's demands. One end of that spectrum for Beatrice might indeed be the lucid strength of her 'be not so passionate' intervention. But the performer must also negotiate the later moment when circumstances 
bring her so low spiritually that she can ask an anxious Crispinella these questions: 'Sister, cannot a woman kill herself? Is it not lawful to die when we should not live?' (5.2.1-2). She persists:

And does not heaven, when it hath made our breath bitter unto us, say we should not live? O my best sister -

To suffer wounds when one may 'scape this rod

Is against nature, that is, against God.

Crispinella's response is the alarmed and grieving 'Good sister, do not make me weep' (13).

The accounts of Beatrice I have cited airbrush this moment out. Similarly, Mark Thornton Burnett and Peter Womack examine the scene closely, but fail to mention that Beatrice begins it in such spiritual disarray that she contemplates suicide as a seductive possibility, despite the contemporary Christian church's unyielding anathema against it; ${ }^{21}$ while Peter Davison invokes the exchange by observing that the play contains 'discussions on censorship and suicide'22 — for all the world, as if the sequence had the detached tone of a philosophical debate.

For the player cast as Beatrice, such evasions are unavailable, unless her director begins the scene with a swingeing cut. This moment of despair represents the extremest point at one end of the spectrum across which her character is driven in the course of the action. In her dark night of the soul, Beatrice comes to seem as if she too can logically claim inclusion in the tribe of 'passionate man'. Her disturbed, and disturbing, trajectory gives the lie to any framing of her as constant, stable, unflinching in her reaction to the world around her. Moment by moment, the play is more complex than such formulae acknowledge.

This is not to deny that the sobriquet of 'passionate man' can be applied to Malheureux too. Critics have also assigned him another tag. Robert Ornstein, for instance, calls him 'a puritanical moralist', while Douglas Bruster has him venting 'a puritanical diatribe.' ${ }^{23}$ Sometimes that adjective's recurrent use hardens into a bolder characterisation, as when Hugh Craig and Brett Greatley-Hirsch dub him Freevill's 'Puritan friend'. ${ }^{24}$ Two historians have plausibly denied, on theological grounds, the latter label's applicability to Malheureux. ${ }^{25}$ Meanwhile, it is often difficult to know what some of the looser uses of 'puritanical' might communicate - not much more perhaps than the writer's distaste for what he or she takes to be Malheureux's principles. But what are those principles?

According to Susan Baker, 'Malheureux speaks for celibacy'. ${ }^{26}$ But where does he do so? Certainly not in the speech (1.1.94-105) she cites to support her claim. His mission there is to dissuade Freevill from visiting the brothel, and he marshals 
all his arguments to that end. He expresses disgust for what he considers to be the debased nature of Freevill's entanglement and itemizes the deleterious consequences it will bring in its wake. Malheureux has received a hostile press for his efforts. One scholar, for example, judges him 'a priggish, inexperienced man who puts his trust in a cloistered virtue'. ${ }^{27}$

The kernel of truth here is that Malheureux enters the play confident he is immune to the brothel's temptations. This ingenuousness means he is riding for a fall, and the play swiftly delivers it. But are his arguments against Freevill's freewheeling oratory necessarily so antipathetic to a modern audience's sensibilities? He expresses abhorrence for the idea of using a sex worker, and of dealing with 'One that sells human flesh', a type of person he memorably dubs a 'mangonist', ie, a 'dealer in slaves, especially prostitutes' (105n). ${ }^{28}$ Is that self-evidently an indefensible position to adopt? It is certainly not, in the early modern period, a distinctively sectarian or extremist one.

And what about Freevill's bravura celebration of prostitution? It is dazzling as a piece of oratorical display, testimony to how he has profited from an educational system which esteemed the ability to defend, impromptu, almost any proposition. But its angle of approach keeps shifting. At one moment he praises the existence of brothels as a necessary defence of the marital bed, in that they provide an outlet for male libido, which might otherwise be employed in making more cuckolds (71-9). At another he proclaims the iron law of economic necessity. It is perfectly logical and defensible, he asserts, that women, in needy circumstances, should sell their only available asset, their bodies, and so provide for themselves and their families (107-18).

But paraphrase makes these arguments seem to be more straightforward in their impact than they sound in practice. His language is laced with ironies. $\mathrm{He}$ argues, for instance, that 'Every man must follow his trade and every woman her occupation' (109-10). He has just invoked the biblical precept that mankind, as a consequence of the Fall, is condemned to labour in 'the sweat of their brows' (108). So, the divine imperative dictating the labour of a husband as, say, carpenter or baker is made to legitimate, by jesting analogy, a wife's becoming a sex worker. He enhances the mischievous effect by his pun on 'occupation'. It means 'calling', 'craft', of course. But the verb 'to occupy' had come to mean 'to penetrate sexually'. ${ }^{29}$ So the text proposes a secondary resonance here. The woman's divinely ordained 'trade' is to open her legs to men for money. Sexist jeering is a recurrent leitmotif in Freevill's wit.

That wit is also characterized by an ability to make a speech swerve in unpredictable directions. An aria which starts out in apparent praise of sex workers, and 
the advantages they afford the men who visit them, segues into a concluding section which proffers two new lines of argument. First, as part of their fair dealing exchange of 'quid for quo', they will revenge themselves on those who buy their services by infecting them with the pox (131-5). So, they have turned from passively obliging to actively malign in an instant. And then follows the extenuating claim that, in a world where everything of value, 'nay, even God himself' (137-8), has been sold, it must be rated only a paltry sin to sell one's body. Freevill manages the switch from one position to another with showy agility.

He rounds off his rhetorical excursion with another piece of profanity: 'For this I hold to be denied of no man: / All things are made for man, and man for woman' (142-3). In a parodic inversion of Genesis 2:18-25, Freevill insinuates that the world was created for woman, and that man is her subservient creature, for, after all, 'But for his mistress, who would care for coin?' (141). The couplet's rhyme, however, reveals a sting in the tail. To chime with 'no man', we need to read in a common early modern pronunciation, 'woe-man', and the wordplay makes the point. Woman brings woe, as in the story of the Fall. And, from an aria which opened with an apparent defence of sex workers' social utility and their right to trade, the target of mockery is now the whole sex, not just those who follow that special 'occupation'.

Where is Freevill in all of this? The surface fireworks are dizzying, the verbal dexterity impressive. But tying down what Freevill himself might really think is almost impossible. Some writers have extrapolated this or that section and made it stand for Freevill's habitual attitudes, ${ }^{30}$ or for the play's world-view. ${ }^{31}$ That, however, entails disregarding the speech's self-ironizing and its constant shifts of perspective and tone. Freevill bows out with 'Give me my fee' (144), as if he were a lawyer, ready to plead whatever case his client requires for hire.

The contrast with how Marston narrates Malheureux's fortunes is emphatic. Malheureux has been mocked for his alleged lack of self-knowledge; but Marston gives him soliloquies in which he struggles to probe his own feelings and see himself more clearly. They are a complex pitch and toss between attempts to fabricate a justification of desires he has customarily regarded as illicit, on the one hand, and contrary impulses of self-rebuke and self-hatred, on the other. The play also clearly maps how Malheureux initially embraces Franceschina's offer of her favours if he kills Freevill, but then, overwhelmed by horror at his own nefariousness, resolves to renege on that commitment and tell his friend of the plot against him. The soliloquy in which he reaches that decision contains lines in which he corrosively indicts his own facility in devising equivocations to validate a course of action he knows to be despicable: 'Lord, how was I misgone! How 
easy 'tis to err / When passion will not give us leave to think!' (2.2.245-6). Such speeches show us, pulse by pulse, the effort Malheureux expends in anatomizing his emotions' true nature and identifying the lack of ethical probity in which they threaten to entrap him.

Marston's writing for Freevill lacks this kind of transparency. Scholars often attribute to him a capacity for strenuous self-interrogation, which has re-routed his life and made him, like a figure in a morality play, turn away from the world of brothel sex to a sincere commitment to marriage and the renunciation of past indulgences this demands. Wine, advocating this reading, affirms that Freevill is therefore 'the only one in the play who can knowingly state its moral'. 32 The lines he chooses to validate this claim are the couplet with which Freevill ends the second scene: 'Of all the fools that would all man out-thrust, / He that 'gainst nature would seem wise is worst' (1.2.184-5). The way Wine cites these words out of context might suggest to a reader unfamiliar with the play that these lines overtly address Freevill's own past follies. But they are not self-rebuke, but de haut en bas mockery of Malheureux's fall from grace.

Overt self-scrutiny — sometimes deluded, sometimes sharply perceptive — is central to Malheureux's soliloquies. The first person pronoun provides the axle on which they turn, from 'That I should love a strumpet! I, a man of snow. / Now, shame forsake me. Whither am I fallen?' (83-4) to 'Lord, how was I misgone. How easy 'tis to err / When passion will not give us leave to think' (2.2.245-6). In contrast, Freevill's soliloquies are phrased impersonally and tend to eschew the use of 'I'. The one notable exception is his soliloquy in 4.2, when he vows to subject his friend to 'repentance, the fool's whip' (31). But his use of 'I' there concerns actions he will perform in relation to Malheureux: 'I'll force thee' (34), 'I'll withdraw' (37), and so on. In its second half Freevill appears to change tack and open himself to interrogation: 'But is this virtue in me? No, not pure - I Nothing extremely best with us endures' (39-40). Spectators will be disappointed if they think he is about to confess what the impure admixture in his motives might be. He provides no fuller answer to the question he himself posed. Instead the soliloquy moves on to aphoristic generalities about 'No use in simple purities' (41), and signs off with the quasi-proverbial declaration that 'The end being good, the means are well assigned' (47). A solo promising to bring self-revelation ends by denying us that possibility.

Opacity of this kind characterizes Marston's handling of Freevill throughout. One can imagine how another dramatist might have shaped his history, to match the diagrammatic progress - from libertine present to uxorious future - commentators claim to discern in it. As Malheureux recoils in disgust at moments 
from the debased craving which made him willing to contemplate his friend's murder, so Freevill would experience a 'road to Damascus' crisis, during which the scales fall from his eyes, and after which he would embrace a new life founded on transformed principles. But Marston has avoided such unequivocally succinct patterning. Indeed, he muddies the waters wherever possible. In the first scene, for instance, he gives us contradictory signals. Freevill has resolved to marry (1.1.72), but declares he will end his night's entertainment by going 'the way of all flesh' (91) - ie, a visit to his courtesan Franceschina. His conversation with her 'does not suggest the termination of their sexual relationship'. ${ }^{33}$ In the next scene he derides Malheureux for his apostasy from his professed beliefs in falling for her in his turn (1.2.163-84), and then exits, only to re-enter immediately before Beatrice's balcony, where he sings her a rapt aubade and hymns her 'chaste eyes', which have 'gaged' his 'soul' to her $(2.1 .3,5)$. Directly thereafter, he switches back to jeering Malheureux with a re-energized remorselessness and demotic viciousness before he companionably revisits Franceschina with him. His motive in this latter action is never made explicit. We might speculate it is to arrange, as they have discussed earlier (2.1.99-105), for his friend to replace him as her lover, though this object is never stated in the dialogue. In the event, his behaviour deliberately? - provokes her into fury, and he sneeringly tells her not to 'turn witch before thy time' (109), before abandoning her permanently.

As with his dizzying display of wit in his initial prostitution aria, the surface fireworks are scintillating, and his investment in each moment highly energized, but plotting a linear progress for him is not something the play assists us with. We observe a sequence of actions, and are given none of the access to Freevill's inner thinking, if such a thing can be presumed to exist, that Marston could easily have arranged. The two roles are crafted in radically distinct ways, and the two players' address to the audience is, consequently, utterly different. Malheureux opens himself to the spectator, inviting empathy, but also risking challenge and even disdain. Freevill is never comparably frank with us and gives no evidence of possessing comparable powers of self-scrutiny.

His later solos are either rhapsodic celebrations of Beatrice as a 'dove-like virgin, without gall' (4.4.91), or contrasting excoriations of Franceschina as 'unreprievable, beyond all / Measure of grace, damned immediately' (5.1.66-7) — exactly the monochromatic polarization that scholarship often assumes the play itself buys into. Freevill draws the lesson that no one 'worthy name of man' would 'leave the modest pleasures of a lawful bed' for 'the unhealthful loins of common loves' $(5.1 .72-3,88)$. The application to himself is apparent, but he never explicitly owns it as such. In one alternative scenario, Freevill might have directly 
admitted the scale of his own transfer of loyalties, and testified to the conviction with which he now embraces a new set of convictions. Instead, he adopts the tone of an absolutist preacher, deriding those who are so inanely reprehensible as not to live by the values he now professes. Views he had himself earlier flamboyantly proclaimed he now objectifies as the crass misconceptions of other people - specifically Malheureux. Freevill's new-found certainties align him with the views he had earlier scorned his friend for espousing, a truth nowhere acknowledged in his dialogue.

Peter Davison felt the play was weakened by its handling of Malheureux after he bows to Franceschina's demand that he kill his friend. Once alone, Davison notes,

he entertains this thought for less than a dozen lines before he begins to doubt and in less than twenty he has realised 'how easy ti's to erre' and decided to tell Freevill all. This does Malheureux's sentiments much credit, and shows, perhaps, the strength of the influence of the concept of friendship, but the play as drama and as an expression of Marston's concerns, is seriously though by no means fatally weakened. The main plot has lost its bite. We never feel, as we do in Measure for Measure, that the threats are serious and the implications real. ${ }^{34}$

In this reading, unless murder remains on the agenda, the play will lack gravitas and be dramatically flawed. But Davison never asks what Marston might have sought to achieve by the tactics he chose.

What is at stake here is pinpointed for me by another debatable statement, this time by Jill Levenson: '[Malheureux's] bad judgement sets off the intrigues and counter-intrigues which call for a sensational resolution in the fifth act'. ${ }^{35}$ She attributes to Malheureux an independent agency he never properly possesses. From the moment which disappointed Davison, Malheureux emerges determined on what he must do: 'Not he that's passionless, but he 'bove passion's wise. / My friend shall know it all' (2.2.252-3). From that cue a playwright might generate a range of different consequences. Marston's choice is to make the two friends' next encounter decisive for them both. It brings, for Freevill, the revelation that Franceschina wanted to procure his death and, for Malheureux, the humbling self-revelation that, despite this, he still 'must use her' (3.1.258). Freevill soon improvises the plot of his faked death, which will allow Malheureux to achieve that ambition. Freevill's tone in this section is worldly-wise, ethically relativist, pragmatic, and thus closely akin to the free-wheeling games-playing of his first 
scene. Witness his cynical exit line: 'What old times held as crimes, are now but fashions' (284).

We might, however, easily imagine alternative scenarios here. Freevill could, for instance, have argued against his friend's subjugation to lust and sought to strengthen him in his struggle against that passion. This choice would have generated the kind of neat inversion of their starting positions Fletcherian theatre so often delights in. Instead, Marston makes Freevill license, even persuade, Malheureux to hope that he can indeed 'use' Franceschina. Only after another duologue with him to the same effect, several scenes later, will Freevill declare, in soliloquy, an intent (not previously hinted at) to reform Malheureux by making him experience 'the worst' (4.2.34). In that same speech Freevill asks us, and himself, whether his behaviour is motivated by pure 'virtue', and then, having raised that doubt, swiftly retreats from clarifying his own motives further. So, the revelation of Freevill's new game-plan is delayed by Marston to a later point than might otherwise have been the case and then is immediately complicated by the hints Freevill himself offers about the ethical complexity, even murkiness, of the impulses driving him.

Levenson's certainty that Malheureux's 'bad judgement sets off' everything that follows ignores the interplay of competing agencies which Marston's action maps. If Freevill did not respond as he does when Malheureux tells him of the murder demand, the 'intrigues and counter-intrigues' Levenson invokes would not occur in their present form. Drama notates and anatomizes how characters act upon one another. Abstracting a single figure from this process and attributing primary agency to that character damagingly simplifies Marston's design.

Davison's objection, founded in presuppositions about what a play should do, misses what Marston has actually done. By making Malheureux unwilling to carry out his promise to Franceschina, he spotlights the significance of Freevill's intervention, which ensures that Malheureux's entanglement with the brothel world is far from over, and that the potential of his 2.2 soliloquy is consequently destined to be left unfulfilled. Marston's theatre is a theatre of surprises - of possibilities trailed but not realized, and of sudden plot swerves which seemingly come out of nowhere, and which challenge us to decode their logic. Davison's strictures, in effect, express a desire that Marston had offered us something more conventional, more easily reconcilable with his pre-set critical preferences.

As our rehearsals progressed, the complexity of the play's handling of Freevill came to be more and more apparent. We spent time exploring, for instance, the bizarreness of his language in the balcony scene with Beatrice. Finkelpearl speaks of the 'ardent avowals' 36 they exchange in this duet and makes their union an 
ethical norm against which to appraise others' shortcomings. But Freevill is no Romeo. He blurts out his concern about what might happen if others were to see and admire her. He would prefer her to be generally disesteemed, as long as she could therefore be guaranteed to rest securely his (2.1.30-5). He concludes: 'He that is wise pants on a private breast' (36). He either assumes that all women, including Beatrice, are fickle and easily seduced, or that he is himself incapable of retaining a wife's loyalty. Either way, we might reasonably deduce that his doubts represent deep-rooted issues, if Marston has them break surface on such an occasion.

One strand in Freevill's 1.1 extravaganza was a defence of brothels as key resources in defending marriage, on the grounds that 'married men love the stews as Englishmen love the Low Countries, wish war should be maintained there, lest it should come home to their own doors' (76-9). The balcony scene suggests that his personal view of marriage is comparably embattled. Predators are everywhere, and their persuasiveness is the decisive factor in determining whether a woman will fall. Implicitly, he credits his wife-to-be with little effective agency in determining her own fate. Even as he affirms his devotion to her, his verse is riddled with worries about the future vulnerability of the bond between them, in ways which question his faith in her ultimate reliability. Such thoughts are not what we might expect to be uppermost in his mind at such a moment. ${ }^{37}$

The paradoxes accumulate as the action develops. Freevill had seemed initially to polarize the worlds of brothel and domestic hearth. Who would predict from this binary that, disguised as his ex-courtesan's pimp, he will later participate in the penetration of the brothel world into his betrothed's home? On that occasion, Franceschina announces his 'death' to Beatrice and torments her with the thought that he died unfaithful to her, while Freevill watches and observes. Some accounts align this incident with the Patient Griselda model. But once again Marston chooses not to make the obvious moves.

When Vindice in The Revenger's Tragedy is commissioned to woo his own sister into prostitution, he uses this opportunity to test her ability to resist temptation and shares those plans with the audience in advance of the event. Marston gives no equivalent speech to Freevill. Instead, we only learn who Franceschina's new pimp is when he enters Beatrice's house with her. Marston might easily have rationalized Freevill's masquerade for him. A soliloquy could have told us that he wished to observe and judge Franceschina's response to his own apparent death, and her treatment of Malheureux thereafter; and then, as events developed, he could have told us that he intended to use her decision to visit Beatrice as an opportunity to observe his betrothed under fire. The latter move might be problematic for us 
now; but the trope of bride-testing is common in early modern drama. Instead, Marston takes Freevill out of camera range, as it were, at the crucial moment and leaves his motives, as so often, opaque.

Having witnessed Beatrice's response to Franceschina's taunts, Freevill lauds her 'suffering sweetness, quiet modesty, / Yet deep affection' (4.4.95-6). For a moment, he thinks of revealing himself, but then, in an extraordinary turn, resolves not to do so: 'No, no! / Grief endears love' (88-9). No modern edition comments on this line, but 'endear' bears a double sense here. One of these is still current: seeing her grieve so pitifully increases his affection for her. But the other meaning is now less familiar: 'To enhance the value of; to render precious or attractive' (OED, endear, $v, 2 \mathrm{a})$. Seeing her in such a state increases his sense of the worth of what he possesses in her, and his relishing of that fact. For this reason, he chooses not to rescue her from her misapprehension, nor to offer relief to the 'tortured mind' (78) with which the news of his apparent death has burdened her.

This decision of his leads to her contemplating suicide, in the striking sequence I discussed earlier. Freevill has treated her grief as if it has effectively reached steady state and can be allowed to continue, so as to increase his delight in her, regardless of the sustained distress this will cause her; but the play, always dynamic in its storytelling, demonstrates that her emotions now possess a dangerous forward momentum of their own. There is a clear chain of consequences here, which even Freevill will briefly recognize later, when he concedes that his 'indiscreet trials' (5.2.49) are to blame for Beatrice's suicidal condition. The voice which authoritatively calls him out on his conduct's effects is Crispinella's. Not content with being 'expressly a secondary character', she instructs him: 'Brother, I must be plain with you: you have wronged us' (64). This moment resonated in our rehearsals and the resulting performances.

\section{Thinking Beyond Marston}

My goal has not been to generate a unitary explanation which seeks to establish a single, 'correct' reading of the textual complexities I am identifying. As I said at the outset, differing performance solutions are possible. But the richness of Marston's achievement is to be discovered in the unruly vivacity of the script's lineby-line intricacies - intricacies too often overwritten by critical formulae which substitute neatly antithetical diagrams for the play's real challenges.

This most mercurial of playwrights delights in the swift oscillations and surprising mutations which the 'soul of lively action' can present to a theatre audience. Every time a commentator, therefore, brackets Freevill as 'a virtuous gentleman' 
and represents Beatrice as a 'passive object to whom men sing Petrarchan love complaints', ${ }^{38}$ we should be aware that the familiar reification of the play's dynamic theatrical potency is once again underway. Such reductive accounts are, as I suggested at the outset, too easily bred by the abbreviated form most modern treatments of it perforce take. The comments cited in the preceding paragraph, for instance, come from a seven-page account of the play in an ambitious, and influential, monograph of 276 pages long. The play's complexities are, in effect, subdued here to the larger rhythms of the controlling narrative which unifies this study.

To begin to convey this brilliant play's full power to readers and, potentially, to spectators, we need to liberate The Dutch Courtesan from such simplifications and notate, as accurately and clearly as we can, the detailed challenges it poses to us, both in our study of the play and in performance. Beyond that, the difficulties anatomized here potentially pose questions about the need to fireproof our explorations of the major works of this repertoire against the temptation to impose static and abstract patternings upon them. Marston, with his addiction to quick-change transformations of tone and bravura generic experimentation, may be an extreme case. But numerous of his peers - Webster, for instance, and Middleton - face us with matching challenges, in their own distinctive, idiosyncratic ways. ${ }^{39}$ The closer our analysis can come to mapping the inventive dynamism of their moment-by-moment craftsmanship, the nearer we will move to releasing once again the energies which make the work of this deeply creative Jacobean generation of playwrights striking and remarkable, and, therefore, also urgently worth restoring to the stage today. 


\section{Notes}

I thank Oliver Jones, Perry Mills, Felicity Riddy, and Richard Rowland for reading this article in draft and commenting helpfully. Any remaining problems in it remain my responsibility.

1 The production was at the department of Theatre, Film, Television and Inter-Active Media at the University of York in June 2013. We created a website - http://www. dutchcourtesan.co.uk/ - to accompany it. In addition to hosting a film of the production, the website includes filmed interviews with key collaborators on the production as well as fifteen new scholarly articles on the play.

2 Mary Bly, Queer Virgins and Virgin Queans on the Early Modern Stage (Oxford, 2000), 69.

3 John Russell Brown points to the recurring impact a one-line role has had in modern performances of Webster's The White Devil. See Shakespeare's Plays in Performance (London, 1966), 226.

4 For a convenient tabulation of the play's principal borrowings from Montaigne's Essays, see John Marston, The Dutch Courtesan, ed. M.L. Wine (London, 1965), $112-20$.

5 Donna B. Hamilton, 'Language as Theme in The Dutch Courtesan', Renaissance Drama 5 (1972), 84, https://doi.org/10.1086/rd.5.41917092.

6 My line calculations follow the numberings in John Marston, The Dutch Courtesan, ed. Karen Britland (London, 2018). Unless otherwise indicated, all further references to the play are to this edition.

7 David Crane, 'Patterns of Audience Involvement at the Blackfriars Theatre in the Early Seventeenth Century: Some Moments in Marston's The Dutch Courtesan', in Plotting Early Modern London: New Essays on Jacobean City Comedy, ed. Dieter Mehl, Angela Stock, and Anne-Julia Zwierlein (Aldershot, Hampshire, 2004), 103.

8 For an exploration of the intricate historical situation concealed by this convenient stereotype, see Michael Cordner, 'Franceschina's Voice', http://www.dutchcourtesan.co.uk/franceschinas-voice/.

9 John Marston, The Dutch Courtezan (London: T.P. for John Hodgets, 1605; stc: 17475), C4r.

10 The Dutch Courtesan, ed. Wine, xvi.

11 Refer, for example, to Eric Bentley's classic exploration in The Life of the Drama (London, 1966), 219-56, 295-353.

12 Martin Wiggins, in association with Catherine Richardson, British Drama 15331642, A Catalogue, 9 vols (Oxford, 2012-19), 5.121. 
13 Philip C. McGuire, Speechless Dialect: Shakespeare's Open Silences (Berkeley, 1985), 63.

14 John Marston, The Malcontent, ed. G.K. Hunter (London, 1975), 6.

15 Philip J. Finkelpearl, John Marston of the Middle Temple: An Elizabethan Dramatist in His Social Setting (Cambridge MA, 1969), 202, https://doi.org/10.4159/harvard.9780674183971

16 The Oxford English Dictionary (OED), s.v. 'mulligrub', n. 1a.

17 Jill Levenson, 'Comedy', in The Cambridge Companion to English Renaissance Drama, ed. A.R. Braunmuller and Michael Hattaway (Cambridge, 1990), 290.

18 Mary Beth Rose, The Expense of Spirit: Love and Sexuality in English Renaissance Drama (1988; Ithaca NY, 1991), 49, https://doi.org/10.7591/9781501723247.

19 Douglas Bruster, Drama and the Market in the Age of Shakespeare (Cambridge, 1992), 87, https://doi.org/10.1017/cbo9780511553080.

20 I call it 'hypothetical' because rehearsal almost invariably reveals that the spectrum is, in practice, wider than one had predicted.

$21{ }^{21}$ Mark Thornton Burnett, "Calling 'things by their right names": Troping Prostitution, Politics and The Dutch Courtesan', in Renaissance Configurations: Voices/ Bodies/Spaces, 1580-1690, ed. Gordon McMullan (Houndmills, Basingstoke, 1998), 177, https://doi.org/10.1057/9780230378667 8; Peter Womack, English Renaissance Drama (2006; Oxford, 2008), 169, https://doi.org/10.1002/9780470690093.

22 John Marston, The Dutch Courtesan, ed. Peter Davison (Edinburgh, 1968), 9.

23 Robert Ornstein, The Moral Vision of Jacobean Tragedy (Madison, 1960), 160; Bruster, Drama and the Market, 88.

24 Hugh Craig and Brett Greatley-Hirsch, Style, Computers, and Early Modern Drama: Beyond Authorship (Cambridge, 2017), 53, https://doi.org/10.1017/9781108120456.

25 Peter Lake, with Michael Questier, The Antichrist's Lewd Hat: Protestants, Papists and Players in Post-Reformation England (New Haven NJ, 2002), 672.

26 Susan Baker, 'Sex and Marriage in The Dutch Courtesan', in In Another Country: Feminist Perspectives on Renaissance Drama, ed. Dorothea Kehler and Susan Baker (Metuchen, NJ, 1991), 222.

27 R.W. Ingram, John Marston (Boston, 1978), 115.

28 The Dutch Courtesan, ed. Britland, 111.

29 David Crystal and Ben Crystal, Shakespeare's Words: A Glossary and Language Companion (London, 2002), 302.

30 Jean E. Howard, Theater of a City: The Places of London Comedy, 1598-1642 (Philadelphia, 2007), 151, https://doi.org/10.9783/9780812202304. 
31 Margot Heinemann, Puritanism and Theatre: Thomas Middleton and Opposition Drama under the Early Stuarts (Cambridge, 1980), 98, https://doi.org/10.1017/ cbo9780511561160.

32 The Dutch Courtesan, ed. Wine, xvii.

33 Garrett A. Sullivan, Jr, “All Thinges Come into Commerce”: Women, Household Labor, and Spaces of Marston's The Dutch Courtesan', Renaissance Drama 27 (1996), 27.

34 The Dutch Courtesan, ed. Davison, 9.

35 Levenson, 'Comedy', 290.

36 Finkelpearl, John Marston of the Middle Temple, 206.

37 For a more extended investigation of the idiosyncratic nature of Marston's writing for Freevill in the balcony scene, see Michael Cordner, 'Mapping The Dutch Courtesan', http://www.dutchcourtesan.co.uk/mapping-the-dutch-courtesan/.

38 Howard, Theater of a City, 151, 153.

39 In the autumn of 2019 we launched a new practice-as-research project at the University of York - Shakespeare's Rivals - which is devoted to exploring the contrasting and divergent demands that different Jacobean playwrights characteristically place upon their performers. Its first public event juxtaposed radically contrasting sequences from Massinger's The Roman Actor, Webster's The Devil's Law-Case, and the Dekker/Ford/Rowley Witch of Edmonton, in a practical exploration of that question. Those performances, as well as some of the rehearsals leading to them, have been filmed and, linked with contextual material, will be made freely accessible on a new website, www.shakespearesrivals.co.uk, in the second half of 2020. A second public event, focused on city comedy, with a primary emphasis on Jonson and Middleton, had been planned for June 2020, before the coronavirus pandemic descended on us. We hope to resume work on that in due course. 
